\title{
Novel mutation of Upshaw-Schulman syndrome associated with coarctation of aorta in Palestinian child
}

\author{
${ }^{1}$ Department of Paediatrics, An-Najah National \\ University Hospital, Nablus, Palestine \\ ${ }^{2}$ Department of Paediatric Haematology-Oncology, An- \\ Najah National University Hospital, Nablus, Palestine \\ ${ }^{3}$ Department of Histopathology, An-Najah National \\ University Hospital, Nablus, Palestine
}

Mahdi Zaid $^{1}$, Sultan Musleh ${ }^{2}$, Tahani Sarrawi ${ }^{2}$, Maysa Alawneh ${ }^{1}$, Reem Sawafta ${ }^{1}$, Honood AbuRas ${ }^{3}$

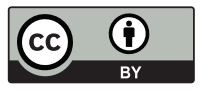

This work is licensed under a Creative Commons Attribution 4.0 International License

Received: 2020-03-08

Accepted: 2020-03-15

UDC: 616.1

J Clin Med Kaz 2020; 1(55):27-31

Corresponding Author: Mahdi Mohammed Zaid,

Department of Paediatrics, Pediatric Resident MD.

An-Najah National University Hospital, Palestine.

Tel.: 00972568210002

Email: Dr.mahdiz@yahoo.com

\section{Abstract}

Upshaw-Schulman syndrome is a rare inherited form of thrombotic thrombocytopenic purpura disease caused by deficiency of ADAMTS13 and reversible by fresh frozen plasma infusions. Unlike the more common acquired thrombotic thrombocytopenic purpura, patient with UpshawSchulman syndrome generally presents early life with a repeated episodes of microangiopathic haemolytic anaemia, usually triggered by acute illness. There are few reported cases about congenital thrombotic thrombocytopenic purpura and long term prognosis.

We describe a 16 months old Palestinian male patient with history of severe neonatal jaundice, microangiopathic haemolytic anaemia and thrombocytopenia triggered by febrile illness associated with facial palsy as neurological manifestation favoured congenital thrombotic thrombocytopenic purpura. Low ADAMTS13 level and improvement in platelet counts after fresh frozen plasma infusion with novel mutation of Leu209Pro in exon 6 of the ADAMTS13 gene confirmed the diagnosis of congenital thrombotic thrombocytopenic purpura in our patient who later on developed coarctation of aorta suggested thrombotic complication of ADAMTS13/VWF missing axis dysfunction.

Key words: Upshaw-Schulman syndrome (USS), congenital thrombotic thrombocytopenic purpura (TTP \section{ЖАНА МУТАЦИЯСЫ \\ М. Заид 1 , С. Муслех ${ }^{2}$, Т. Саррауи ${ }^{2}$, М. Алауних ${ }^{1}$, Р. Сауафта ${ }^{1}$, Х. АбуРас ${ }^{3}$ \\ 'Педиатрия бөлімі, Ан-Наджа Ұлттық Университеттік ауруханасы, Наблус, Палестина \\ Педиатриялық гематология және онкология бөлімшесі, Ан-Наджа Ұлттық Университеттік ауруханасы, Наблус, Палестина \\ ${ }^{3}$ Гистопатология бөлімі, Ан-Наджа Ұлттық Университеттік ауруханасы, Наблус, Палестина}

ПАЛЕСТИНАЛЫҚ БАЛАДАҒЫ ҚОЛҚА ТАРЫЛУЫМЕН БАЙЛАНЫСТЫ АПШОУ-ШУЛЬМАН СИНДРОМЫНЫН

\section{тұЖЫРЫМДАМА}

Апшоу-Шульман синдромы - ADAMTS13 жетіспеушілігінен туындаған және жаңа мұздатылған плазманың инфузиясы арқылы қайтымды болатын тромботикалық тромбоцитопениялық пурпураның сирек кездесетін тұқым қуалайтын түрі. Жиі кездесетін тромботикалық тромбоцитопениялық пурпурадан айырмашылығы, Апшоу-Шульман синдромы бар науқастың балалық шағында әдетте өткір аурудан туындаған микроангиопатиялық гемолитикалық анемия жиі кездеседі. Туа біткен тромботикалық тромбоцитопениялық пурпураның және ұзақ мерзімді болжамның бірнеше тіркелген жағдайлары бар.

Бұл зерттеуде ауыр неонатальды сарғаю, туа біткен тромботикалық тромбоцитопениялық пурпураға тән неврологиялық көрінісі ретінде бет парализімен байланысты фебрильді аурудан туындаған микроангиопатиялық гемолитикалық анемиямен және тромбоцитопениямен ауыратын 16 айлық палестиналық баланың жағдайы сипатталады.

ADAMTS13 деңгейінің төмендігі және ADAMTS13 6 генінің экзонында Leu209Pro жаңа мутациясымен жаңа мұздатылған плазманы инфузиялағаннан кейін тромбоциттер санының жақсаруы біздің науқаста туа біткен тромботикалық тромбоцитопениялық пурпураның диагнозын растады, ол науқаста кейінірек қолқа тарылуы анықталды, болжам бойынша жоқ ADAMTS13/VWF осьтік дисфрункциясының тромботикалық асқынуы болуы мүмкін.

Негізгі сөздер: Апшоу-Шульман синдромы, туа біткен тромботикалық тромбоцитопениялық пурпура, жаңа мутация, ADAMTS13, фон Виллебранд факторы, қолқа тарылуы 


\section{НОВАЯ МУТАЦИЯ СИНДРОМА АПШОУ-ШУЛЬМАН, СВЯЗАННАЯ С КОАРКТАЦИЕЙ АОРТЫ У ПАЛЕСТИНСКОГО РЕБЕНКА}

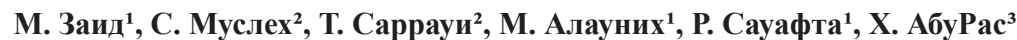

'Отделение педиатрии, Национальная университетская больница Ан-Наджа, Наблус, Палестина

${ }^{2}$ Отделение педиатрической гематологии и онкологии, Национальная университетская больница Ан-Наджа, Наблус, Палестина

${ }^{3}$ Отделение гистопатологии, Национальная университетская больница Ан-Наджа, Наблус, Палестина

\section{PEЗЮME}

Синдром Апшоу-Шульмана является редкой наследственной формой тромботической тромбоцитопенической пурпуры, вызванной дефицитом ADAMTS13 и обратимой с помощью инфузий свежезамороженной плазмы. В отличие от более распространенной приобретенной тромботической тромбоцитопенической пурпуры, пациент с синдромом Апшоу-Шульмана обычно в детстве имеет частые эпизоды микроангиопатической гемолитической анемии, обычно вызванной острым заболеванием. Есть несколько зарегистрированных случаев врожденной тромботической тромбоцитопенической пурпуры и отдаленного прогноза.

В настоящем исследовании описывается случай пациента, 16-месячного палестинского мальчика с тяжелой неонатальной желтухой в анамнезе, микроангиопатической гемолитической анемией и тромбоцитопенией, вызванной фебрильной болезнью, связанной с параличом лица, как неврологическим проявлением, характерным врожденной тромботической тромбоцитопенической пурпуре. Низкий уровень ADAMTS13 и улучшение количества тромбоцитов после инфузии свежезамороженной плазмы с новой мутацией Lеu209Pro в экзоне 6 гена ADAMTS13 подтвердили диагноз врожденной тромботической тромбоцитопенической пурпуры у нашего пациента, у которого позднее выявилась коарктация аорты, предположительно тромботическое осложнение отсутствующей осевой дисфункции ADAMTS13/VWF.

Ключевые слова: Синдром Апшоу-Шульмана, врожденная тромботическая тромбоцитопеническая пурпура, новая мутация, ADAMTS13, фактор фон Виллебранда, коарктация аорты

\section{Introduction}

Upshaw-Schulman syndrome (USS) or Congenital thrombotic thrombocytopenic purpura (TTP) is a rare lifethreatening recessively inherited disease characterized by thrombocytopenia, microangiopathic haemolytic anaemia, microvascular thrombosis and ischemic damage of multiple organs with end stage renal failure or neurological sequelae in the absence of appropriate treatment. It can be congenital or acquired; Congenital TTP is associated with a genetic mutation in ADAMTS13, which cuts von Willebrand factor into smaller pieces, thereby formation of unnecessary blood clots. Acquired TTP, seen more often in older age secondary to anti-ADAMTS13 autoantibodies [1,2]. Congenital TTP is a rare genetic disorder with an estimated incidence of 4-10 cases per million/year [3]. Diagnosis can be suggested by the normalization of platelet count after fresh frozen plasma infusion, which may has a dual therapeutic and diagnostic advantage [4].

\section{Case report}

We report a 16 months old Palestinian male patient, full term with uncomplicated pregnancy, weighted 3100 gm at birth. Patient was admitted at NICU with severe indirect hyperbilirubinemia developed during first $24 \mathrm{~h}$ of life, associated with fever, cyanosis and tachycardia. Therefore, urgent blood exchange transfusion was done and patient improved. Both maternal and infant's blood groups were $\mathrm{A}+$ with negative Coombs test. G6PD enzyme assay level was normal. During infancy, patient was in a good health condition except for a two episodes of mild febrile illness associated with hypoactivity, decrease feeding and occasional isolated low platelets counts, ranges between 50-150 X 109 (Normal 135-465 X 109/L).

At age of 16 months, patient presented with high grade fever and sudden onset right sided facial palsy associated with severe thrombocytopenia, platelet counts 34x 109/L. So, he referred to our Paediatric Haematology and Oncology Department for further evaluation and management.

At presentation, patient was irritable, pale with loss of forehead wrinkling, inability to close eyes and absent naso-labial fold on right side. No palpable lymph nodes or hepatosplenomegaly.

Initial laboratory evaluation revealed isolated thrombocytopenia, Platelets count 25 X109, Reticulocytic count $7.5 \%$, negative direct Coomb's test, Haptoglobulin 0mg/dL (normal, 22-164), lactate dehydrogenase (LDH) level 1417U/L (normal $=180-430 \mathrm{U} / \mathrm{L})$, Peripheral smear showed numerous schistocytes and helmet cells with few nucleated red cells.
Bone marrow biopsy and aspirate showed hypercellularity with increase erythroid precursors and adequate megakaryocytes in keeping with peripheral consumption. Blood cultures revealed no growth. Other labs as renal function tests, coagulation profiles, antinuclear antibodies (ANA), iron profiles, immunoglobulins levels and Haemoglobin electrophoresis all were all within normal.

Brain MRI and MR angiography were done to rule out upper motor neuron lesion as CNS tumour, thrombosis or focal lesions which causing this facial palsy, which showed few small acute lacunar infarcts seen scattered in both cerebral hemispheres (cortical, white matter and right basal ganglia) in addition to abnormal bilateral cerebral white matter signal intensities (Figure 1). CSF glucose, protein WBC, culture and PCR for Herpes simplex I and II were within normal.

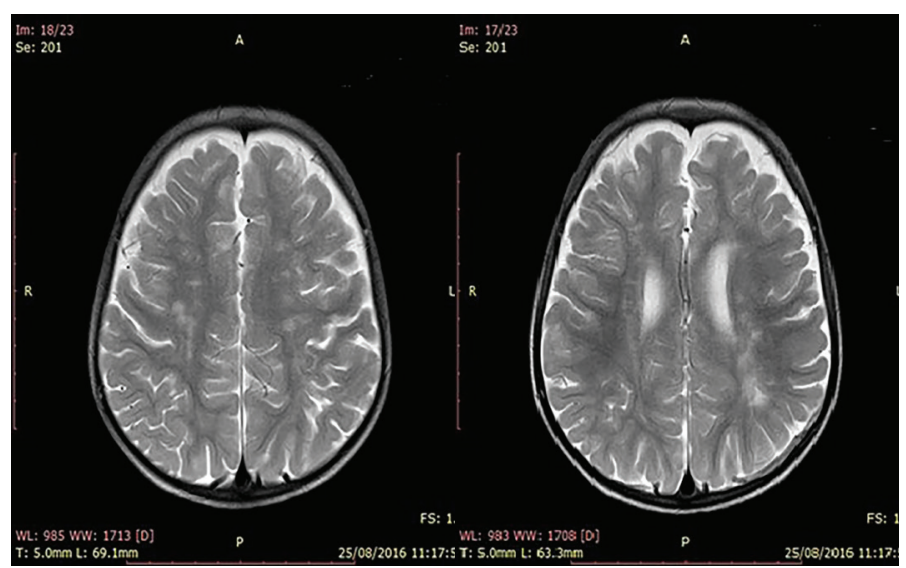

Figure 1 - Small acute lacunar infarcts seen scattered in both cerebral hemispheres (cortical, white matter and right basal ganglia) in addition to abnormal bilateral cerebral white matter signal intensities.

The diagnosis of thrombotic thrombocytopenic purpura (TTP) was made based on clinical presentation, laboratory findings and neurological sequel (facial palsy). Therefore, plasma infusion in addition to 3 sessions of plasma exchange was done. So ADAMTS13 activity assay sent and showed low ADAMTS13 level without ADAMTS13 antibodies. Genetic study for ADAMTS13 gene mutation was sent for confirmation. Platelet counts started to increase gradually with rapid improvement of facial palsy till it recovered completely.

After one month with regular plasma exchange every 
two weeks, genetic test result confirmed the diagnosis of congenital Thrombocytopenic Purpura showing homogeneous ADAMTS13 gene mutation of Leu209Pro at exon 6, which was not documented before.

Patient was kept on regular plasma transfusion every 2 weeks till age of 31 months, by this time when he presented for routine plasma transfusion, he was drowsy and hypoactive. His vital signs showed high blood pressure reading in the arms with low blood pressure in the lower extremities, (right arm 150/91 $\mathrm{mmHg}$, left arm 155/94 mmHg, right leg 97/71 mmHg, and left leg 95/68 mmHg).

Urgent echocardiogram was done that showed narrowed segment of the aortic arch and descending aorta with near occlusion of the distal part. So patient underwent aorta resection and end to end anastomosis.

\section{Discussion}

Upshaw-Schulman Syndrome (USS) is a synonym for Congenital thrombotic thrombocytopenic purpura (CTTP), was first described in 1960 by Schulman et al in an 8-yearold girl born in Germany with bleeding tendency, recurrent thrombocytopenia and microangiopathic haemolytic anaemia (MAHA), but without specific clotting factor abnormalities. The episodes were transiently but dramatically corrected by the infusion of fresh frozen plasma (FFP). Therefore, the authors expected a congenital deficiency of a plasma plateletstimulating factor [5]. In 1978, Jefferson D. Upshaw described a 29 -year-old woman who had a history of recurrent bleeding episodes from the age of 6 months to 12 years, characterized by thrombocytopenia and MAHA, similar to Schulman's case [6]. Furthermore, they submitted the appellation of UpshawSchulman syndrome (USS) for such cases.

USS is a rare life-threatening disease which inherited through an autosomal recessive pattern. It is caused by mutations in the gene encoding ADAMTS13 on chromosome 9q34, and to date, there have been many distinct reported mutations spreading all over the ADAMTS13 gene [7]. The most commonly reported mutation of ADAMTS13 is c.4143dupA (p.Glu1382Argfs) mostly in Northern and Central European countries [8,9]. In this Palestinian case, we found homogeneous mutation of Leu209Pro in exon 6 of the ADAMTS13 gene, which is unreported before.

ADAMTS13 enzyme, which is synthesised mainly in the liver and vascular endothelium, plays an important role in haemostasis by regulating the size of von Willebrand factor (VWF) that is produced in endothelial cells and megakaryocytes [10].ADAMTS13 cleaves hyperactive ultra-large von Willebrand factor (ULVWF) multimers into smaller and less active multimers [11]. ADAMTS13 deficiency is prothrombotic, where excessive amounts of ULVWFs result in platelet aggregation by binding circulating platelets spontaneously and causing systemic microvascular platelet thrombi that induce embolic ischemic damage to end organs as brain, heart and kidney, which defining TTP [12]. But this alone is unable to precipitate acute symptoms. Thus, usually prompted by stress-inducing triggers that required to activate the endothelium and release von Willebrand factor (e.g. hyperbilirubinemia, infection, trauma or pregnancy) [13].

The most common presentation of USS is the neonatal onset of severe hyperbilirubinemia requiring an exchange blood transfusion with negative Coombs test and thrombocytopenia, haemolytic anaemia and the presence of schizocytes on the peripheral smear. Repeated episodes of thrombocytopenia occur in $80 \%$ of patients that reversed by FFP infusion [1416]. The classical pentad of fever, MAHA, thrombocytopenia, neurological and renal abnormalities is found in up to $9 \%$ of cases [17].

TTP crises can be associated with progressive renal deterioration in approximately $50 \%$ of cases, where $20 \%$ of them deteriorated to chronic or end-stage renal disease. Cerebral vascular accidents progressed in about one third of patients, with a risk of neurologic sequelae in approximately $20 \%$ of patients $[18,19]$. In our case, patient had bell's palsy at time of diagnosis, which resolved gradually after two sessions of plasma exchange. It is unknown whether this is due to episodes that affect the central nervous system in the neonatal period with severe hyperbilirubinemia, or on top of repeated but less severe episodes subsequently.

It is unknown whether neurological, renal, cardiac, cognitive, or vascular complications can be prevented by prophylactic plasma therapy [20]. In this case, after one year of diagnosis with regular plasma transfusion every 2 weeks, patient accidently noticed to have high blood pressure that was found later due to narrowed segment of the aortic arch and near occlusion at distal part of descending aorta, so patient underwent urgent repair by coarctation of aorta resection and creation of end to end anastomosis.

There are two possible explanations for this vascular complication. First, it could be an accidental combination and the systemic deficiency of ADAMTS13 has no impact on developing coarctation of aorta. Second, ADAMTS13 and VWF play an opposite role in thrombosis and systemic inflammation [21]. ADAMTS13 deficiency lead to an increase in leukocyte adhesion and extravasation under acute inflammatory conditions $[21,22]$. It also results in an accumulation of ultra large VWF multimers on endothelial cell surfaces and in plasma, which enhances both platelet aggregation and systemic inflammation. This hypothesis is based on a number of published studies showing the accumulation of ULVWF strings on endothelial cells upon injury in Adamts13-/- mice mainly in the regions of disturbed blood flow, which are highly prone to atherosclerotic lesion development as carotid sinus, aorta and aortic sinus [2126].

TTP is considered a medical emergency, so plasma therapy (plasma exchange or plasma infusion) should be obtained immediately if we suspect TTP. The correction of thrombocytopenia by plasma therapy has a dual diagnostic and therapeutic action in TTP. ADAMTS13 activity provides valuable information contributing to the diagnosis of TTP. Severe deficiency in ADAMTS13 considered if it less than 10\%, which is highly indicative of congenital thrombotic thrombocytopenic purpura (TTP) in an appropriate clinical setting [27]. Not all patients with a clinical diagnosis of thrombotic thrombocytopenic purpura (TTP) have severe ADAMTS13 deficiency, other nonTTP conditions might have mild to moderate ADAMTS13 deficiency $(\leq 10 \%)$. These conditions include haemolytic uremic syndrome, disseminated intravascular coagulation, sepsis, pregnancy, liver diseases or certain medications. Therefore, TTP remains a clinical diagnosis and should be confirmed by detection of a homozygous or compound heterozygous mutation upon sequencing of ADAMTS13 gene on chromosome 9q34 to prove hereditary form and exclude acquired TTP and other nonTTP conditions having ADAMTS13 activity deficiency [28-31].

Nowadays, plasma therapy (plasma exchange or plasma infusion) alone, is the mainstay of treatment and prevention of acute episodes of USS. Although ADAMTS13 has a half-life of only $2-3$ days, plasma infusions $(10-15 \mathrm{mg} / \mathrm{kg})$ every $2-3$ weeks are sufficient to prevent relapse episodes of the disease and maintain normal platelets count. Approximately 50\% of USS patients exhibit relapses especially with neonatal onset 
that clearly requires regular prophylaxis and close observation after stress situations (e.g. infection, vaccination, trauma and pregnancy) [32].

Rituximab administration showed by several reports a favourable outcomes in prevent relapse of TTP among more than $90 \%$ of patients with relapsed or refractory TTP by depleting anti-ADAMTS13 antibodies [33,34].

Nowadays, Recombinant ADAMTS13 replacement instead of plasma infusion in the treatment and prophylaxis is a clinical trial which can be applied in near future, this can minimize the potential risks of recurrent plasma infusions as infections, circulatory overload and anaphylactic reactions [35].

\section{Conclusion}

USS is a rare congenital TTP diagnosis based on the clinical presentations and confirmed by genetic finding. An ADAMS13 gene mutation of Leu209Pro at exon 6 is novel one that was not reported before, and this is the first reported case that showed the association with coarctation of aorta.

Disclosures: There is no conflict of interest for all authors.

Patient informed consent: obtained.

\section{References}

1. Fujimura, Yoshihiro, et al. Von Willebrand Factor-Cleaving Protease and Upshaw-Schulman Syndrome. International journal of hematology. 2002; 75(1):25-34. https://doi.org/10.1007/BF02981975

2. Zheng, Xinglong, et al. Structure of von Willebrand factor-cleaving protease (ADAMTS13), a metalloprotease involved in thrombotic thrombocytopenic purpura. Journal of Biological Chemistry. 2001. 276(44):41059-41063. https://doi.org/10.1074/jbc.C100515200

3. Pérez-Rodríguez, Almudena, et al. Inherited ADAMTS13 deficiency (Upshaw-Schulman syndrome): a short review. Thrombosis research. 2014; 134(6):1171-1175. https://doi.org/10.1016/j.thromres.2014.09.004

4. Sadler, J. E. von Willebrand factor assembly and secretion. Journal of Thrombosis and Haemostasis. 2009; 7:24-27. https://doi. org/10.1111/j.1538-7836.2009.03375.x

5. Schulman, Irving, et al. Studies on thrombopoiesis: II. Assay of human plasma thrombopoietic activity. The Journal of pediatrics. 1965; 66(3):604-612. https://doi.org/10.1016/S0022-3476(65)80124-X

6. Upshaw Jr, Jefferson D. Congenital deficiency of a factor in normal plasma that reverses microangiopathic hemolysis and thrombocytopenia. New England Journal of Medicine. 1978; 298(24):1350-1352.) https://doi.org/10.1056/NEJM197806152982407

7. Joly, Bérangère S., et al. ADAMTS13 Gene Mutations Influence ADAMTS13 Conformation and Disease Age-Onset in the French Cohort of Upshaw-Schulman Syndrome. Thrombosis and haemostasis. 2018; 118(11):1902-1917. https://doi.org/10.1055/s-0038-1673686

8. Schneppenheim, Reinhard, et al. A common origin of the 4143insA ADAMTS13 mutation. Thrombosis and haemostasis. 2006; 96(07):3-6. https://doi.org/10.1160/TH05-12-0817

9. Kokame, Koichi, et al. Mutations and common polymorphisms in ADAMTS13 gene responsible for von Willebrand factorcleaving protease activity. Proceedings of the National Academy of Sciences. 2002; 99(18):11902-11907. https://doi.org/10.1073/ pnas. 172277399

10. Crawley, James TB, et al. Unraveling the scissile bond: how ADAMTS13 recognizes and cleaves von Willebrand factor. Blood. 2011; 118(12):3212-3221. https://doi.org/10.1182/blood-2011-02-306597

11. Sadler, J. Evan. What's new in the diagnosis and pathophysiology of thrombotic thrombocytopenic purpura. ASH Education Program Book. 2015; 2015(1):631-636.' https://doi.org/10.1182/asheducation-2015.1.631

12. Nokes, Timothy, et al. Pulmonary involvement in patients with thrombotic thrombocytopenic purpura. European journal of haematology. 2014; 92(2):156-163. https://doi.org/10.1111/ejh.12222

13. Furlan, Miha, Bernhard Lämmle. Aetiology and pathogenesis of thrombotic thrombocytopenic purpura and haemolytic uraemic syndrome: the role of von Willebrand factor-cleaving protease. Best practice \& research Clinical haematology. 2001; 14(2):437-454. https://doi.org/10.1053/beha.2001.0142

14. Yagi, Hideo, Masanori Matsumoto, Yoshihiro Fujimura. Paradigm shift of childhood thrombotic thrombocytopenic purpura with severe ADAMTS13 deficiency. La Presse Médicale. 2012; 41(3):e137-e155. https://doi.org/10.1016/j.lpm.2011.10.027

15. Lotta, Luca A., et al. Residual plasmatic activity of ADAMTS13 is correlated with phenotype severity in congenital thrombotic thrombocytopenic purpura. Blood. 2012; 120(2):440-448. https://doi.org/10.1182/blood-2012-01-403113

16. Scully, Marie, et al. Guidelines on the diagnosis and management of thrombotic thrombocytopenic purpura and other thrombotic microangiopathies. British journal of haematology. 2012; 158(3):323-335. https://doi.org/10.1111/j.1365-2141.2012.09167.x

17. Dawod, Muath, Mohammad Alhyari, Philip Kuriakose. Patterns of Clinical Presenations of Thrombotic Thrombocytopenic Purpura in Plasma Exchange Era. 2012; 4642-4642.] https://doi.org/10.1182/blood.V120.21.4642.4642

18. Deschênes, Georges, et al. Plasma therapy in von Willebrand factor protease deficiency. Pediatric Nephrology. 2002; 17(10):867-870. https://doi.org/10.1007/s00467-002-0944-9

19. Loirat, Chantal, et al. Thrombotic thrombocytopenic purpura associated with von Willebrand factor-cleaving protease (ADAMTS13) deficiency in children. Seminars in thrombosis and hemostasis. 2006; 32(02). https://doi.org/10.1055/s-2006-939764

20. George, James N. Forecasting the future for patients with hereditary TTP. Blood. 2012; 120(2):243-244. https://doi.org/10.1182/ blood-2012-05-427419

21. Jin, Sheng-Yu, et al. Genetic ablation of Adamts13 gene dramatically accelerates the formation of early atherosclerosis in a murine model. Arteriosclerosis, thrombosis, and vascular biology. 2012; 32(8):1817-1823. https://doi.org/10.1161/ATVBAHA.112.247262

22. Gandhi, Chintan, et al. ADAMTS13 reduces vascular inflammation and the development of early atherosclerosis in mice. Blood. 2012; 119(10):2385-2391. https://doi.org/10.1182/blood-2011-09-376202

23. Chauhan, Anil K., et al. ADAMTS13: a new link between thrombosis and inflammation. Journal of Experimental Medicine. 2008; 205(9):2065-2074.j https://doi.org/10.1084/jem.20080130 
24. De Maeyer, Bauke, et al. The distal carboxyterminal domains of murine ADAMTS13 influence proteolysis of platelet-decorated VWF strings in vivo. Journal of Thrombosis and Haemostasis. 2010; 8(10):2305-2312.] https://doi.org/10.1111/j.1538-7836.2010.04008.x

25. Chauhan, Anil K., et al. Systemic antithrombotic effects of ADAMTS13. Journal of Experimental Medicine. 2006; 203(3):767-776. https://doi.org/10.1084/jem.20051732

26. Mannucci, Pier Mannuccio, et al. Changes in health and disease of the metalloprotease that cleaves von Willebrand factor. Blood. 2001; 98(9):2730-2735. https://doi.org/10.1182/blood.V98.9.2730

27. Mannucci, Pier Mannuccio, Flora Peyvandi. TTP and ADAMTS13: when is testing appropriate? ASH Education Program Book. 2007; 2007(1):121-126. https://doi.org/10.1182/asheducation-2007.1.121

28. Peyvandi, F., et al. ADAMTS-13 assays in thrombotic thrombocytopenic purpura. Journal of Thrombosis and Haemostasis. 2010; 8(4):631-640. https://doi.org/10.1111/j.1538-7836.2010.03761.x

29. Meyer, Sara Christina, et al. Hyperbilirubinemia interferes with ADAMTS-13 activity measurement by FRETS-VWF73 assay: diagnostic relevance in patients suffering from acute thrombotic microangiopathies. Journal of thrombosis and haemostasis. 2007; 5(4):866-867. https://doi.org/10.1111/j.1538-7836.2007.02438.x

30. Starke, Richard, et al. The clinical utility of ADAMTS13 activity, antigen and autoantibody assays in thrombotic thrombocytopenic purpura. British journal of haematology. 2007; 136(4):649-655. https://doi.org/10.1111/j.1365-2141.2006.06471.x

31. Sadler, J. Evan. Von Willebrand factor, ADAMTS13, and thrombotic thrombocytopenic purpura. Blood. 2008; 112(1):11-18.' https:// doi.org/10.1182/blood-2008-02-078170

32. Camilleri, R. S., et al. A phenotype-genotype correlation of ADAMTS13 mutations in congenital thrombotic thrombocytopenic purpura patients treated in the United Kingdom. Journal of Thrombosis and Haemostasis. 2012; 10(9): 1792-1801.] https://doi.org/10.1111/ j.1538-7836.2012.04852.x

33. Scully, Marie, et al. A phase 2 study of the safety and efficacy of rituximab with plasma exchange in acute acquired thrombotic thrombocytopenic purpura. Blood. 2011; 118(7):1746-1753. https://doi.org/10.1182/blood-2011-03-341131

34. Zwicker, Jeffrey I., et al. Adjuvant low-dose rituximab and plasma exchange for acquired TTP. Blood. 2019. https://doi.org/10.1182/ blood.2019000795

35. George, James N. Congenital thrombotic thrombocytopenic purpura: Lessons for recognition and management of rare syndromes. Pediatric Blood And Cancer. 2008; 50(5):947. https://doi.org/10.1002/pbc.21481

How to cite this article: Mahdi Zaid, Sultan Musleh, Tahani Sarrawi, Maysa Alawneh, Reem Sawafta, Honood AbuRas. Novel mutation of Upshaw-Schulman syndrome associated with coarctation of aorta in Palestinian child. J Clin Med Kaz. 2020; 1(55):27-31 